\title{
The Impact of Personal Experience on the Professorial Practice in Physical Education: A Case Study from Tunisia
}

\author{
Hejer Ben Jomaa1,2, Donia Sghaier,3,4 Mohamed Mami ${ }^{3,4}$ \\ ${ }^{1}$ Higher Institute of Sports and Physical Education, University of Manouba, Ksar Saïd, Tunisia \\ ${ }^{2}$ EDic, UMR EFTS, Toulouse University, Jean-Jaures, France \\ ${ }^{3}$ Higher Institute of Sports and Physical Education, University of Jendouba, Kef, Tunisia \\ ${ }^{4}$ Research Unit of Sportive Performance and Physical Rehabilitation, Higher Institute of Sports and Physical \\ Education, Kef, Tunisia \\ Email: Hejer.bjh@laposte.tn, doniasghaier@ymail.com,mami.analyst@gmail.com
}

Received 3 May 2016; accepted 24 June 2016; published 27 June 2016

Copyright (C) 2016 by authors and Scientific Research Publishing Inc.

This work is licensed under the Creative Commons Attribution International License (CC BY).

http://creativecommons.org/licenses/by/4.0/

(c) (i) Open Access

\section{Abstract}

The observation of teaching practices of physical education (PE) at secondary school (Terrisse \& Carnus, 2009) shows some differences at the level of "teaching thinking" (Tsangaridou, 2008), teaching conceptions and knowledge references. Indeed, Physical Education teacher can transmit knowledge by referring in multiple references. He teaches institutional knowledge (school curricula). However, he transmits also personal knowledge, personal conception and personal link to knowledge stemming from his personal experience and his sportive expertise. The research methodology is qualitative and descriptive. We refer to the clinical didactic methodology organized with three times constructed temporality. The aim of this case study (Terrisse, 2003) is to understand whether personal experience, revealing of teaching thinking, influences the nature and the form of teaching practice and the professional activity of a PE teacher during the teaching-learning process.

Keywords

Personal Experience, Clinical Didactics, PE Teacher, Link to Knowledge

\section{Introduction}

A lot of researches in pedagogy and didactics, in the current of research on teacher thinking, show not only that

How to cite this paper: Jomaa, H. B., Sghaier, D., \& Mami, M. (2016). The Impact of Personal Experience on the Professorial Practice in Physical Education: A Case Study from Tunisia. Creative Education, 7, 1328-1334.

http://dx.doi.org/10.4236/ce.2016.79137 
the process of teaching is complex and multidimensional, but that the behavior and the actions of the teachers, during the process learning-teaching, are widely influenced by what they think (Tsangaridou, 2008).

If the act of teaching is, on one hand, presented as an interactive, complex and professional activity, on the other hand this process must be examined as a result of a conscious or unconscious decision of the teacher. Indeed, knowledge, conceptions, faiths and values are conceived as explanatory elements of the behavior and actions of the teachers because they supposed to influence them (Calderhead, 1987). The primary objective of this current paper is to examine the impact of personal experience on practice teaching and didactic action of a PE teacher.

This comparative study proposes to examine the singularity of the teaching act. It relies on the study "case by case" or "one by one" (Terrisse, 1999). In this context, we are interested in the analysis of subject's singularity and complexity in the PE didactic framework. Our attention will be focused on the personal history of each teacher (Carnus et al., 2013) through the study of his "personal already these" (Carnus, 2003; Ben Jomaa, 2014). We are interested in the teaching of two Physical and Sporting Activities (PSA): sports specialty and another sports activity, by the same teacher. In the first time, we observe a cycle of gymnastics. Teacher $C$ knows specifically this PSA. He practiced it since his childhood, as sports specialty. In the second time, we observe a cycle of basketball. Teacher C does not know enough this PSA because his doesn't practice it outside the school. However he must teach it because of institutional programming and school curricula.

\section{Problematic and Research Questions}

We postulate that the "teacher C" hasn't got the same link to knowledge, to body and to PSA. The theoretical and methodological tools allow us to describe and explain this comparison and join a particular epistemological position: the PE clinical didactic. The question of knowledge delivered in class is certainly dependent, on one hand on the institutional constraints already described by Chevallard since 1991, on the other hand it is certainly dependent on the personal constraints which structure the teaching subject and which can explain the causes of some didactic phenomena (Ben Jomaa et al., 2007; Ben Jomâa \& Terrisse, 2011). Indeed, the teacher is a "didactic subject". He is autonomous and responsible. His personal history, his private approach and his professional epistemology are central elements in his decisions (Carnus in Terrisse et al., 2009).

The present research study sought to provide answers to the following questions:

1. Does personal experience influences the nature of knowledge transmitted and the practice of teaching?

2. Is there a relationship between personal didactic approach (link to knowledge, references of knowledge, link to PSA) and professional practices?

\section{Conceptuel Framework}

In this research, we refer to the concept of link to knowledge. It's a fundamental concept/reference for the study of knowledge transmission in PE, even in the other disciplines. Indeed, this didactic concept implies the consideration of the way that a subject is affected by knowledge (De Leonardis, Laterrasse, \& Hermet, 2002). Certainly, this notion takes us back to at least three references: didactic, sociological and psychoanalytical. But its aim is to analyze the transformations, which infer the apprenticeship in terms of corporeal transformations for pupils and teaching conceptions for teacher. Therefore, we mean by link to knowledge the creative process of a donor (subject) of sense (Beillerot, Blanchard-Laville, \& Mosconi, 1996).

We also refer to the concept of break of the didactic contract (BDC) as an object of didactic study susceptible to explain certain dysfunctions and to think of the didactic phenomena in terms of regulation. The didactic contract is defined by Brousseau (1986) as a system of mutual, explicit and implicit obligations, which determines what every partner is responsible for the apprenticeship (for pupils) and the contingency management (for teacher). The specificity of the contract lies in its tendency to be negotiated as an anti-contract because it is subdued to the contingency of the didactic situation. This BDC consists in the transformations of knowledge object connected to the modifications-explicit or implicit of knowledge stakes (Reuter, Cohen-Azria, Dauney, Delcambre, \& Lahanier-Reuter, 2007). This notion serves as an analysis tool of the teacher expertise through the way which the teacher transmits knowledge. These can be interpreted from the speeches (verbatim) and from the didactic gestures used by the teacher such as the ostension. This latter is defined as the monstration of knowledge, by differentiating it in direct, verbal and gestural according to the scale of Salin (2002), for giving pupils an image of corporeal gesture and to identify the distance that the teacher has from knowledge (Berdot, Blan- 
chard-Laville, \& Camara Dos Santos, 1997). Thus, we use the distinction personal/official knowledge as an analysis indicator allowing to show the weight of the personal/official knowledge in the speech (and gestures) of the teacher during the management phases of the BDC. Indeed, we use indicators produced by our research (and spotted in the verbatim of the teacher before, during and after the teaching act) to identify the personal knowledge (what comes from the teacher as personal life, as corporeal felt and teaching desire) from the one who is official, presented in the official texts (school curricula, institution of school reference and project of establishment).

\section{Methodology}

\subsection{Research Participant}

A male and beginner teacher named "teacher C" voluntarily participated in this study. He taught PE in secondary school for 2 years. He is specialist of gymnastics, see Table 1 and agrees to teach two different PSA, that is three sessions of the cycle of gymnastics and three sessions of the cycle of basket-ball.

\subsection{Data Collection}

The filming took place between the $28^{\text {th }}$ of January, 2014 and the $16^{\text {th }}$ of August, 2014. Before the first interview "a priori", a first visit allowed us to list, with the teacher, the available space and material (the state of place).

The data analysis is organized around three phases of the clinical didactic methodology of the PE systematically used:

- Before the session: this time corresponds to a priori analysis of the "already-there experiential et conceptual" of the teacher through the analysis of his link to PSA (interview a priori) and to knowledge to be taught in gymnastics and basketball (interview "ante" session and analysis of theoretical contents of sessions).

- During the session: it is the time of knowledge transmission event. The filming and the transcription of the video recordings allow here to analyze what takes place effectively in situ.

- After the session from the interview of "after event", a moment when the teacher explains his version of the progress of the various sequences and the sense that he attributes to his practice and to the transmitted knowledge.

Data were collected using the video observation (filming) and interviews: a priori, ante session, post session and "post stroke". Our corpus constituted of audio and video recordings of a PE teacher leading the second, the third and the fourth basket-ball and gymnastics session. We refer to the clinical didactic methodology. This methodology is organized with three distinct times constructed temporality: the "already-there", the "test" and the "post stroke" (Terrisse, 2000). Consequently, we take in account in priority and in postoriority what singularizes the processes of learning-teaching and the professorial activity from epistemological and didactic point of view.

\subsection{Data Analysis}

For the data analysis, we refer to the clinical didactic methodology organized around three analysis phases systematically used: before, during and after the teaching act and the data triangulation process. We used also the retranscription of verbatim and the analysis of the clinical interview, the content's analysis (Van Der Maren, 1996; Bardin, 1998) and the analytical reading (Starobinski, 1970).

Table 1. The sports practice of the teacher C.

\begin{tabular}{ccc} 
& Gymnastics (PSA 1) & Basket-ball (PSA 2) \\
\hline $\begin{array}{c}\text { Duration of the sports } \\
\text { practice }\end{array}$ & $\begin{array}{c}\text { Twelve years of the Sports practice } \\
\text { (inscription to regional/national sports teams). }\end{array}$ & $\begin{array}{c}\text { Absence of sports practice: } \\
\text { ordinary school practice. } \\
\text { Accomplished level of performance }\end{array}$ \\
Trainer's practice & Sedals on a national and international scale. \\
At present & (regional/national sports teams). \\
\end{tabular}

Legend: PSA 1: the specialty; PSA 2: the non-speciality. 


\section{Results}

\subsection{The Case of Specialty Teaching}

Personal link to PSA: the gymnastics is very significant for the teacher $\mathrm{C}$ arousing in him several feelings which are sometimes contradictory: such us personal interest, sacrifices, suffering and pleasure. His personal link to this activity marked him strongly: "teaching gymnastics is a pleasure for me, I like do it, it's my sports specialty, I don't care about"'.

Personal conception of teaching: specifically, during the teaching of the sports specialty (gymnastics), the teacher exposed and recognized knowledge which is connected to his personal link to knowledge and personal experience such as the gymnastic posture, that is confirmed in the interview of "post stroke": "I felt that I teach something which is in me, that I already have, my gymnast's posture". This personal knowledge is particularly a part of his "sports lived" and recovers from this fact of process of formalization and personal integration of knowledge.

Personal link to body: in this study, we take into account the link to body as the constituent element of the personal expertise of the teacher as both a specialist and a determiner of his teaching process. Indeed, expert teacher transmits a corporeal knowledge. He uses essentially the direct physical ostension (DPO) total or partial (Salin, 2002; Sghaier et al., 2016) stemming from his corporeal expertise to expose the knowledge to pupils. He transmits incorporated and personal knowledge. From Table 2 and Figure 1 presented below, we can discuss that the teacher $\mathrm{C}$ uses differently the ostensive forms. Indeed, he refers to the direct physical ostension (corporeal demonstration) in the teaching of sports specialty. However, when he teaches the second PSA (the non-specialty or basket-ball) he refers especially to the direct verbal ostension (DVO). Furthermore, his corporeal practice influences the nature of ostensive forms used and his knowledge proximity.

The Advance of knowledge and the link to contingency: globally, the specialist teacher thinks about knowledge to be transmitted to his pupils: "for me, I have never smelt any difficulties in gymnastics; I can anticipate what is going to take place with my pupils, I think about my teaching". So, he is in the anticipation. Interestingly,

Table 2. Ostensive procedures used in gymnastics and basket-ball.

\begin{tabular}{ccccc}
\hline Teacher C & DPO & DVO/PPO & Dig. O & No. O \\
\hline Gymnastics & 23 & 09 & 0 & 0 \\
Specialty & $(71 \%)$ & $(29 \%)$ & $(0 \%)$ & $(0 \%)$ \\
Basket-ball & 10 & 23 & 0 & 0 \\
Non-specialty & $(30 \%)$ & $(70 \%)$ & $(0 \%)$ & $(0 \%)$ \\
\hline
\end{tabular}

Legend: DPO: direct physical ostension; DVO/PPO: direct verbal and/or physical private ostension; Dig. O: disguised ostension; No. O: no ostension.

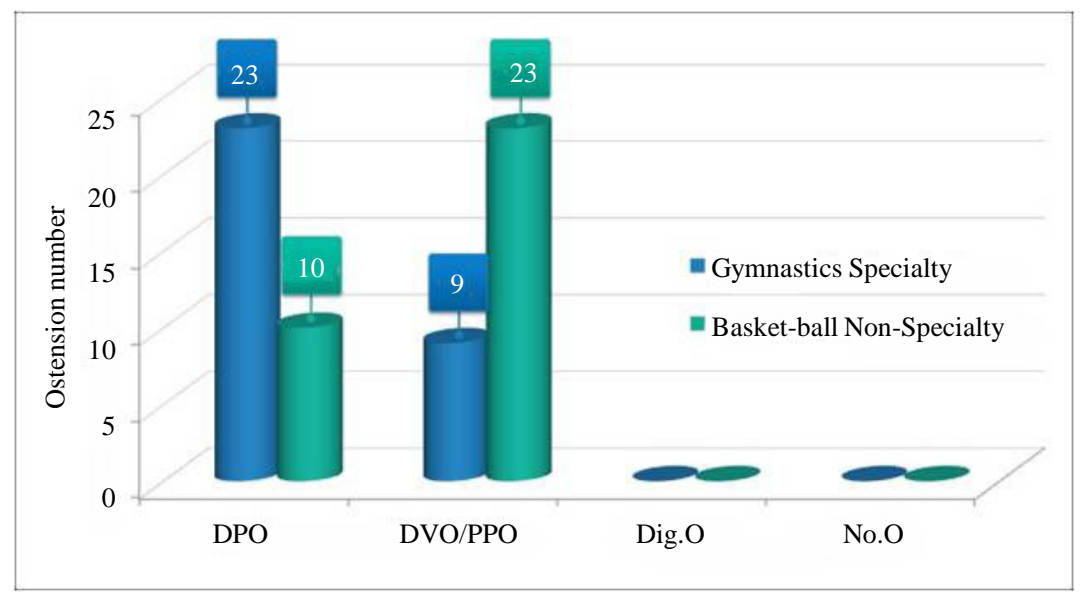

Figure 1. Ostensive procedures used in gymnastics and basketball by teacher " $\mathrm{C}$ ".

${ }^{1}$ All the quotations in italics are extracted from the teacher's speech before, during or after the lesson. 
he decodes the pupils' practices thanks to his own knowledge in the activity. Indeed, the expert teacher has also singular strategies of contingency allowing him to manage the breaks of the didactic contract (manage the didactic contract ruptures) by referring to the personal knowledge and to the personal forms of ostension. Thinks to his specific link to contingency, he assumes his didactic responsibility for the advance of knowledge and the mastery of pupils (class management) in class. It is not the case when the teacher discovers at the same time as the pupils these difficulties and he cannot resolve them for lack of adaptation (adaptation fault). As a result, teacher C is regarded as professional in education (Altet, 1991; Paquay 1994), with expertise and effectiveness in terms of adaptation, autonomy and reflection (Schön, 1994, 1996; Berliner, 1986; Siedentop et al., 1989). In fact, reflexive practice allows teachers to improve their professional conduct (Kpazai \& Attikleme, 2012; Legault, 2004; Sebren, 1995; Smyth, 1984).

\subsection{The Case of Non-Specialty Teaching}

Official link to PSA: The teacher C presents basket-ball as an “aggressive, complicated and binding” PSA which is practiced in an "uncertain and variable milieu”: "I don't like teaching basket-ball, it is not my trick, I don't know it enough...Eh... but I must do it”. His official link to PSA characters his speech. For him, teaching the basket-ball is an institutional constraint.

Official conception of teaching: the nature of knowledge transmitted in the teaching of the non-specialty allows us to show the dominant part of the official knowledge marking the transmission process. Indeed, the lack of personal experience and corporeal practice in the activity leads (conduit) the teacher to refer to the official knowledge while staying in his simple planning to preserve class didactic mastery, especially when he is novice in the professional practice: "I transmitted the technical fundamental gestures with and without ball mentioned in the programs". Therefore, we notice, particularly, an official conception teaching on the teaching of the second activity.

A different link to contingency: contrary to the adaptation process marking the link to contingency in specialty teaching, the teacher expresses his fear of the unforeseen, the loss of mastery and his difficulty supporting the class situation contingency. Indeed, he does not know how to solve the unforeseen problems connected to the pupils' apprenticeship: “sometimes I can't solve the problem because I can't find the solution”. So, this distance to his planning prevents him to venture into a contingency, which could not be managed and shows his immediate link to knowledge.

\section{Discussion}

This paper discusses the impact of the personal experience and the sportive expertise on the teaching activity. We argue that the subjective resources in terms of personal link to knowledge, personal link to PSA, personal link to contingency and personal link to body affect the practice teaching of PE and determine the teaching conceptions (Buznic, 2009; Jourdan in Terrisse et al., 2009). However, we do not intend to generalize our results because it is about a single case study. Our analysis becomes attached to the fact that the most singular of a personal experience can show any universal human condition through a generic frame of invariants applicable, in the professional training context, to a certain extent to every teacher (novice, experimented, specialist or not) confronted with different PSA teaching.

\section{Conclusion}

As a conclusion, this comparative didactic analysis shows that personal experience influences the teaching act and the professional practice. Indeed, the personal experience, in terms of personal "reflection" of "thinking”, appears to contribute to the raising of awareness of the teacher's "social role as a professional” (Kpazai \& Attikleme, 2012). Taking into account the personal dimension of teaching is, in contemporary society, an indicator of professionalism in teachers because this dimension makes them real educative actors. Therefore, the scientific research needs to develop tools that permit the optimization of professional training of PE teachers. There is a need for professional training institutions to develop the conditions that underpin innovation. As noted above, to moving from the specific (case study) to the general, this research demonstrates that thinking in the pursuit of professional training optimization appears to be an emerging process. However, if professional expertise allows us to think that teaching as a "personal thinking”, other elements as the impact of the teaching on the pupils learning could constitute in the pursuit of this way of research. 


\section{References}

Altet, M. (1991). Competences of Professional Teacher between Knowledge, Action Schemes and Adaptation, Be Able to Analyse. In L. Paquay, M. Altet, E. Charlier, \& P. Perrounoud (Eds.), Train Professionalteachers. What Are the Strategies? What Are the Competence? (3rd ed., pp. 27-40). Bruxelle: De Boeck University.

Bardin, L. (1998). The Analysis of Contents. Paris: PUF.

Beillerot, J., Blanchard-Laville, C., \& Mosconi, N. (1996). For a Clinical link to Knowledge (pp. 51-74). Paris: Harmattan.

Ben Jomâa, H., \& Terrisse, A. (2011). From the Expertise to the Teaching: Comparative Analysis of the Link to Knowledge of Two Teachers of PE Having Different Sports Specialties. Education and didactics, 5, 61-79. Rennes: PUR.

Ben Jomâa, H., \& Terrisse, A. (2014). The Effect of the Already There on the Practice of a Teacher: The Point of View of the Clinical Didactics. Researches in Education, 20, 116-128. CREN. University of Nantes.

Ben Jomâa, H., Terrisse, A., \& Berhaim, A. (2007). The Weight of the Expertise in the Teaching of the PE: The Signature of the Teacher and the Practices Differentiation. EJRIEPS, 11, 82-98. Besançon: IUFM of Franche-Comté.

Berdot, P., Blanchard-Laville, C., \& Back Santos, C. (1997). The Construction of the Psychic Space in the Class. Variations on a Lesson of Mathematics. Paris: Harmattan.

Berliner, D. (1986). The Expert Pedagogue Pursuit. Educational Research, 15, 5-13. London: Methuen. http://dx.doi.org/10.3102/0013189X015007007

Brousseau, G. (1986). Foundations and Methods of the Didactics of the Mathematics. Researches in Didactics of the Mathematics, 7, 33-115.

Buznic-Burgeacq, P. (2009). The Transmission of the Knowledge of Experience. Case Studies and Comparative Analyses in Clinical Didactics of the PE. Doctoral Thesis, Toulouse: UPS.

Calderhead, J. (Ed.) (1987) Exploring Teacher's Thinking. London: Cassel Education.

Carnus, M.-F. (2003). Didactic Analysis of the Teacher's Decision Making Process in Gymnastics: A Study of Crossed Cases. In C. Amade-Escot (Ed.), Physical Education Didactics, Research Condition (pp. 195-224). Paris: PE Review.

Carnus, M.-F. (2009). The Decision of the Teacher in Clinical Didactics: Case Study in PE. In A. Terrisse, \& M.-F. Carnus (Eds.), Clinical Didactics of the PE: What Stakes in Knowledge? (pp. 47-68). Paris: De Boeck University.

Carnus, M.-F., \& Terrisse, A. (2013). Clinical Didactics of Physical Education, the Subject in Question. Paris: PE Review.

Chevallard, Y. (1991). The Didactic Transposition: From the Learned Knowledge to the Taught Knowledge. Grenoble: The Wild Thought.

De Leonardis, M., Laterrasse, C., \& Hermet, I. (2002). The Link to Knowledge: Concepts and Operationalizations. In C. Laterrasse (Ed.), The Link to Knowledge at School and at University. Paris: The Harmattan.

Jourdan, I. (2009). A Study in Clinic Didactics: Form Report to Knowledge among Students at the PE Initial Formation. In A. Terrisse, \& M. F. Carnus (Eds.), Clinic Didactics, What Are the Issues to Know? Bruxelles: De Boeck University.

Kpazai, G., \& Attikleme, K. (2012). The Role of Professional Experience on the Dimension of Reflexivity in Teaching: A Case Study of Two Secondary School Health and Physical Education Teachers. Journal of Human Sport and Exercise, 7, 254-262. http://dx.doi.org/10.4100/jhse.2012.71.04

Legault, J. P. (2004). Train Reflexiveteachers. Montréal: Editions Logiques.

Paquay, L. (1994). Towards a Reference Table of Professional Skills of the Teacher. Research and Training, 16, 7-38.

Reuter, D., Cohen-Azria, C., Dauney, B., Delcambre, I., \& Lahanier-Reuter, D. (2007). Dictionary of the Fundamental Concepts of Didactics. Thesis, Brussels: De Boeck University.

Salin, M.-H. (2002). Ostensive Practices of Teaching of Mathematics as the Object of Job Analysis of the Professor. In P. Venturini, C. Amade-Escot, \& A. Terrisse (Eds.), Studies of the Effective Practices: The Approach of Didactics. Grenoble: Thought Savage.

Schön, D. (1994). Le Praticien Réflexif. Montréal: Editions Logiques.

Schön, D. (1996). Le Tournant Réflexif, Pratiques éducatives et études de cas. Montréal: Editions Logiques.

Sebren, M. A. (1995). Preservice Teachers’ Reflexions and Knowledge Development. Journal of Teaching in Physical Education, 14, 262-283.

Sghaier, D., Ben Jomâa, H., Mami, M., \& Bouassida, A. (2016).The Combination of the Physical Ostension to the Verbal Ostension in Swimming Revealing of Professorial Action. Creative Education, 7, 500-505.

http://dx.doi.org/10.4236/ce.2016.73051

Siedentop, D., \& Eldar, E. (1989). Expertise, Experience and Effectiveness. Journal of Teaching in Physical and Sporting Education, 8, 254-260. 
Smyth, J. (1984). Teacher as Collaborators in Clinical Supervision: Cooperative Learning about Teaching. Teacher Education, 24, 60-68.

Starobinski, J. (1970). The Critical Relationship. Paris: Gallimard.

Terrisse, A. (1999). The Question of the Link to Knowledge with Teaching Apprenticeship Process: The Clinical Point of View. Carrefour Education, 7, 62-87.

Terrisse, A. (2000). Clinic Research Epistemology in Combat Sports. Researches in Combat Sports and in Martial Arts: Place Conditions and Perspectives, Research Collection and Formation, Paris: PE Review Editions.

Terrisse, A. (2003). Consideration of the Subject and the Researches in Didactics of the Combat Sports. Science and Motricité, 50, 55-79. http://dx.doi.org/10.3917/sm.050.0055

Terrisse, A., \& Carnus, M.-F. (2009). Clinical Didactics of the PE: What Stakes in Knowledge? Paris: De Boeck University.

Tsangaridou, N. (2008). Trainee Primary Teachers’ Beliefs and Practices about Physical Education during Student Teaching. Physical Education and Sport Pedagogy, 13, 131-152. http://dx.doi.org/10.1080/17408980701345667

Van Der Maren, J.-M. (1996). Methods of Research in Education. Brussels: De Boeck University.

\section{Submit or recommend next manuscript to SCIRP and we will provide best service for you:}

Accepting pre-submission inquiries through Email, Facebook, Linkedin, Twitter, etc A wide selection of journals (inclusive of 9 subjects, more than 200 journals)

Providing a 24-hour high-quality service

User-friendly online submission system

Fair and swift peer-review system

Efficient typesetting and proofreading procedure

Display of the result of downloads and visits, as well as the number of cited articles

Maximum dissemination of your research work

Submit your manuscript at: http://papersubmission.scirp.org/ 